\title{
Housing estate greenery in shaping the quality of housing environment on the example of Bialystok
}

\author{
Marta Baum \\ https://orcid.org/0000-0002-6956-9583 \\ m.baum@pb.edu.pl
}

Department of Agri-Food Engineering and Environmental Management, Białystok University of Technology

\begin{abstract}
Summary: The housing environment is the basic area of human functioning, which via its quality affects the state of people's health and well-being. One of the main factors determining the high quality of the housing environment is an appropriate indicator of green areas per 1 inhabitant, which gives the opportunity to create friendly common spaces as well as the nature of the greenery itself. The article presents the analyzes of selected Białystok housing estates which implementation was based on various guidelines and indicators regulating the size of green areas in housing estates. The conducted research allowed to state that urban norms applied in the $20^{\text {th }}$ century provided the best indicator of green areas per capita. Replacing them with a biologically active area ratio has minimized green areas in housing estates and it is becoming necessary to develop new urban indicators to improve the quality of the housing environment.
\end{abstract}

Keywords: housing estate greenery, urban indicators, urban normative, housing environment, Białystok

\section{Introduction}

The housing environment is the basic area of human functioning. It's here where a person rests, fulfills one's needs as well as struggles with daily duties. By its quality, the environment affects the state of health and well-being of the modern man and makes it possible to achieve a sense of social cohesion [Schneider-Skalska 2017].

The main element conditioning the quality of the housing environment, besides the spatial structure that gives a sense of security (by hierarchizing the space, maintaining it in a proper technical condition and on a human-friendly scale), is the presence of natural elements. Properly shaped greenery and water exert a positive influence on human condition and functioning. Through their size and diversity they affect the local climate [Kobylarczyk 2018]. They are an important parameter determining the quality of common spaces which give the possibility of social integration in the estate, shaping the identity and the uniqueness of the place [Szulczewska, Giedych 2011].

The very surface of green areas in the housing estate is also important for the quality of the housing environment. The type of rest, recreation and sport activities in the housing estate depend on the estate's size and the defined user. From the users , and inhabitants' point of view, the area of green areas per one inhabitant is one of the most important indicators determining the standard of living in a residential environment and in a city [Zachariasz 2017]. 


\section{Materials and methods}

The assessment of the housing environment quality due to the equipment in green areas per one inhabitant and type of greenery was made on the basis of:

analysis of the subject literature,

- knowledge of selected urban projects of multi-family housing estates in the city of Białystok,

- valorization of housing development (green inventory as well as development and equipment of green areas in housing estates).

Multi-family housing development has been continuously implemented in Bialystok since the end of World War II. Housing estates were implemented in changing political and economic conditions over time, and hence it happened based on for various guidelines and indicators regulating the size of green areas in housing estates.

- Established until the 1990s, designed on the basis of existing at the time urban norms and implemented by housing cooperatives.

- Established in the new political conditions after 1989, designed based on for spatial development plans and building conditions, implemented in whole or partly by housing cooperatives.

- Residential complexes designed and implemented after 2000 on the investment rules of a free market (developer, private investor) also based on spatial development plans and decisions on building and land development conditions.

Three Białystok housing estates were selected for the research: Osiedle Białostoczek, Osiedle Nowe Miasto II and Apartamenty Jagiellońskie.

The review of the housing estates was based on existing studies [Kłopotowski 2016, Dąbrowska-Milewska 2005], in which the authors group the housing estates of Białystok into individual decades of the $20^{\text {th }}$ and $21^{\text {st }}$ centuries and discuss their urban structure. Individual analysis of the spatial layout in selected housing estates with inscribed green areas was carried out through the prism of applying the criteria of current norms and applying the biologically active area factor. Then a comparative assessment of the housing estates' green areas was made.

\section{Results}

Until the end of the 1990s, green areas in housing estates in Poland were designed on the basis of applicable norms. They contained surface guidelines, determined in relation to the number of inhabitants, population density as well as the radius and range of service and frequency of use and the program guidelines (greenery and recreation) related to the user category [Zachariasz 2017]. They have undergone many changes and repeals as they lost their relevance as a result of economic and technical changes and also the progress of knowledge. The last binding one was the Urban Normative for residential areas from 1974 ${ }^{1}$, which, thanks to its indicators, enabled the protection of appropriate green areas in housing estates (Table 1).

It provided from 25.0 to $30.0 \mathrm{~m}^{2}$ green area and recreation per capita in the isochrone of 800 meters [Dąbrowska-Milewska 2010]. The above-cited indicators guaranteed the possibility of relaxation after work, joint activities and facilitated social integration within the estate. However, they required the designation of large areas of land, and not every local government had such [Kobylarczyk 2018].

The political changes of 1989 affected the outdation of most normative assumptions. In 1994, the Spatial Development Act was adopted, which contributed to the deep liberalization in planning and the lack of introduction of any new urban standards or norms. The Construction Law and Regulation on the technical conditions of buildings and their location were also developed [Komar R. 2014]. The Regulation introduced the concept 
of a biologically active area ${ }^{2}$ and specified its minimum area (25\%) in multi-family housing areas, calculated as the ratio of the biologically active area to the plot area. However, the calculation only takes into account the area occupied by elements considered to be biologically active, and not the diversity in the structure of plants [Giedych, 2015]. New economic conditions (land prices, privatization, development market) as well as the use of only biologically active area parameters led to the intensification of development, fragmentation of the spatial structure of housing estates (fencing, acoustic screens) and the deficit of green social spaces in residential areas [Schneider-Skalska, 2017]. Green areas implemented in the form of gardens on roofs and terraces of residential buildings and on the underground garages that are legally permitted are often the only form of green areas in the estate. This limits future residents' access to compact green areas which give people the possibility of recreation, rest and social integration [Kłopotowski, 2016].

Table 1. Greenery, leisure and sport program for residential areas in cities [Zachariasz, 2006]

\begin{tabular}{|c|c|c|c|c|}
\hline $\begin{array}{l}\text { Level of population } \\
\text { service }\end{array}$ & $\begin{array}{l}\text { Service } \\
\text { coverage }\end{array}$ & The type of open space & $\begin{array}{c}\text { Area demand } \\
\text { indicator } \\
{\left[\mathrm{m}^{2} / \mathrm{M}\right]}\end{array}$ & $\begin{array}{c}\text { Access } \\
\text { isochron } \\
\text { [minutes] }\end{array}$ \\
\hline \multirow{4}{*}{ ELEMENTARY } & \multirow{4}{*}{$\begin{array}{l}\text { Backyard } \\
\text { zone }\end{array}$} & net estate green areas & 8,0 & \multirow{4}{*}{ - } \\
\hline & & $\begin{array}{l}\text { playgrounds for children up to } \\
6 \text { years old }\end{array}$ & 0,6 & \\
\hline & & $\begin{array}{l}\text { playgrounds for children } \\
6-11 \text { years old }\end{array}$ & 1,0 & \\
\hline & & backyard recreation for adults & 0,4 & \\
\hline \multirow{2}{*}{ BASIC } & \multirow{2}{*}{ Estate } & recreation and sports areas & 5,5 & 15 \\
\hline & & children's gardens (Jordanian) & $1,0-1,2$ & $10-30$ \\
\hline \multirow{2}{*}{ ABOVE BASIC } & \multirow{2}{*}{ District } & recreation and sports areas & 5,0 & \multirow{2}{*}{-} \\
\hline & & lawns & 1,0 & \\
\hline
\end{tabular}

This is a dissonance even to British guidelines, where in housing complexes larger than 50 family flats per one inhabitant there should be $20.0 \mathrm{~m}^{2}$ of open green space [Kobylarczyk, 2018]. On the other hand, German indicators which use a converter for 1 flat predict a size of a playground of $\min .60 \mathrm{~m}^{2}\left(5.0 \mathrm{~m}^{2} / 1\right.$ apartment), in location ensuring visual and voice contact with an apartment. There is a need for a playground for older children after 50 flats above. After exceeding 75 providing access to sports grounds for teenagers and adults - assuming a conversion rate of $5.0 \mathrm{~m}^{2} / 1$ apartment, and seating places and tables for games for seniors is obligatory [Schneider-Skalska, 2004].

Therefore, views on the need to develop new urban standards in order to secure spatial needs for green areas appear in the Polish architectural environment. G. Schneider-Skalska proposes comprehensive proposals the implementation of which will affect the creation of a healthy housing environment. She postulates the dependence of the multiplicity and equipment of the designed housing estate greenery on the number of apartments [Schneider-Skalska, 2004]. Whereas G. Dąbrowska-Milewska in her work proposes the division of green areas into (Table 2): home, basic and post-primary areas of public sport and recreation, for which it determines surface indicators, minimum surfaces and maximum access radius [Dąbrowska-Milewska, 2010].

2 The surface of the biologically active area, in accordance with the Regulation of the Minister of Infrastructure of 22 April 2002 on the technical conditions to be met by buildings and their location, is: "native land covered with vegetation and surface water on a construction plot, as well as $50 \%$ of the total terraces and flat roof surfaces, arranged as permanent lawns or flower beds on the ground ensuring their natural vegetation, with an area of not less than $10 \mathrm{~m}^{2 \prime \prime}$ 
Table 2. Recommended program-surface indicators for green areas and backyard recreation, publicly available green areas, recreation and sport [Dąbrowska-Milewska, 2010]

\begin{tabular}{|c|c|c|c|c|}
\hline & Program & $\begin{array}{l}\text { Minimum } \\
\text { area }\end{array}$ & $\begin{array}{l}\text { Indicators of } \\
\text { minimum area }\end{array}$ & $\begin{array}{l}\text { Max access } \\
\text { radius }\end{array}$ \\
\hline \multirow{2}{*}{$\begin{array}{l}\text { Household areas } \\
\text { within a net } \\
\text { construction plot }\end{array}$} & $\begin{array}{l}\text { Playgrounds for the children of } \\
\text { the max 7-year-old children }\end{array}$ & \multirow{2}{*}{$250 \mathrm{~m}^{2}$} & \multirow{2}{*}{$5 \mathrm{~m}^{2} / \mathrm{mk}$} & $50 \mathrm{~m}$ \\
\hline & $\begin{array}{l}\text { Playgrounds for older children } \\
\text { (over } 50 \text { flats) }\end{array}$ & & & $100 \mathrm{~m}$ \\
\hline \multirow{2}{*}{$\begin{array}{l}\text { Basic public } \\
\text { recreation and sport } \\
\text { areas }\end{array}$} & Estate garden & \multirow[b]{2}{*}{2 ha } & $4,0 \mathrm{~m}^{2} / \mathrm{mk}$ & \multirow[b]{2}{*}{$500 \mathrm{~m}$} \\
\hline & Sport fields for team sports & & $1,5 \mathrm{~m}^{2} / \mathrm{mk}$ & \\
\hline \multirow{2}{*}{$\begin{array}{l}\text { Above basic } \\
\text { recreational and } \\
\text { sport areas }\end{array}$} & Parks & \multirow{2}{*}{2 ha } & $4,0 \mathrm{~m}^{2} / \mathrm{mk}$ & \multirow{2}{*}{$1000 \mathrm{~m}$} \\
\hline & $\begin{array}{l}\text { Groups of sport fields, indor } \\
\text { swimming pools, sports halls }\end{array}$ & & $2,5 \mathrm{~m}^{2} / \mathrm{mk}$ & \\
\hline
\end{tabular}

Urban planning standards of programming the green areas binding in the $20^{\text {th }}$ century, the currently applicable biologically active area indicator, as well as the proposed new urban indicators were and are intended to secure the area for residential green areas.

It is equally important to normalize the spatial structure of greenery in a housing estate with the use of indicators. Because, not only does the surface of the green matter in shaping a healthy housing environment, but also the right proportions of tall to low types of flora [Szulczewska, Giedych, 2011]. Already in the 1970s, it was postulated that the guidelines for designing should specify the minimum volumes of greenery that should be envisaged in the designs [Skibniewska, 1979].

Ecological and spatial indicators are already used in Europe and around the world. The main indicators which have an established position in shaping the spatial and natural structure of cities are: Biotope Area Factor - BAF (1994 Berlin), Green Space Factor - GF (2001 Malmo), Gryneery Provision - GnP (2005 Singapore), Seattle Green Factor - SGF (2007 Seattle) $)^{3}$. Their goal is to limit the negative impact of new investments on the natural environment in urban areas and to ensure proper living conditions for residents by: reducing the urban heat island, improving air quality, biodiversity protection and adequate rainwater management. The size of indicators is the ratio of ecologically active areas multiplied by an appropriate converter to the plot area, where, in addition to permeable surfaces, the general area covered with flora, additionally, areas covered by trees, shrubs and creepers are taken into account [Giedych 2015].

\section{Case studies}

The Białostoczek housing estate, completed in 1977-1986, is the largest housing estate among the areas selected for research - area: about 62 ha, population: about 10.5 thousand. Designed and implemented based on the Urban Normative for residential areas from 1974. Through perpendicular settings standardized buildings ( 5 and 11-storey buildings made in the OW-T system) created very diverse semi-open inter-block spaces, giving the possibility of individual arrangement of recreation places and playgrounds for children. The area of green areas in the net areas in the estate is about 10.7 ha. An area on the outskirts of the housing estate in the Biała River valley was allocated for the recreational garden and complex of physical recreation facilities. Unfortunately, the estate park was never implemented, and the area was left to the be managed in the distant

3 Biotope Area Factor (BAF) developed for the needs of landscape plans carried out in Berlin, Green Space Factor (GF) developed for the revitalization of the West Port in Malmo, modeled on Berlin indicators, Gryneery Provision (GnP) is one of the components of the Green Mark (Green Mark) awarded since 2005 in Singapore for investments in ecological solutions, Seattle Green Factor (SGF) indicator used for zones designated in the city's spatial policy, originally it was only applicable for areas with a commercial function, from 2010, the obligation to use it was introduced for housing with a residential function. 
future. Currently, it is an undeveloped open area with low greenery of approximately 11.3 ha. Green in the estate are, first of all, fruit trees (a remnant of gardens and orchards of the former village) and plantings mainly from deciduous trees and shrubs, with a high predominance of high greenery. The adjacent gardens have lost their utility character and are currently dominated by decorative vegetation.

The Nowe Miasto II housing estate was implemented in the years 1990-2002 based on the Detailed Spatial Development Plan, with an area of approximately 30 ha and a population of 9,400. Residential buildings based on 4 and 5-storey buildings. The original plan assumed a housing estate consisting of 8 groups and a reserve of land for a school and estate park, which was eventually allocated for buildings. The first two teams built by the housing association were designed taking into account the guidelines of the Normative of 1974, which translated into extensive interiors with a fully adapted stand. Other housing complexes have already been implemented by development companies, and here the economic factor prevailed, which resulted in reducing the distance between buildings, building density and trimming green areas. All teams have applied the principle of creating shared interiors by stopping off inter-block spaces with playgrounds and leisure places as well as attractively composed, neat, low greenery. The area of inter-block greenery in the estate is about 5.6 ha. The intensification of buildings and the introduction of underground garages resulted in the necessity of constructing green terraces on garage roofs in order to obtain the appropriate factor of biologically active area. Their area is about 0.13 ha. The estate has a small recreational area equipped with: two playgrounds, a playground and an outdoor gym covering the space of 0.58 ha (that is what is left in the open area intended for the estate park). Settlement greenery is mainly low plantings from shrubs and short trees with a predominance of conifers, as well as perennial beds.

One may be tempted to state that the housing estate in question is a transitional form between multi-family housing estates of the modern period and currently implemented housing complexes.

The Apartamenty Jagiellońskie residential complex, the implementation of which has begun in 2017, was designed on a plot of approximately 3 ha based on a planning permission. Expected population is about 2.5 thousand (conversion of 3 people to 1 apartment). The complex consists of four 11-storey, detached buildings arranged longitudinally in relation to the street. However, due to their nature (C-shaped) they do not form a compact frontage. The landscaping did not use the terrain configuration as well as the attractive neighborhood of the Biała River Valley and adjacent open areas. There was also no connection between individual buildings, because the greenery of the complex was implemented entirely on the garage panels of individual buildings, which makes them separate "islands" detached from the surrounding open areas. The green areas of each building consist of: fenced green terraces assigned to apartments on the first floor, a common space with a small playground and slopes resulting from covering the garage walls. The total area of green areas in the complex is about 0.58 ha (common area - playground 0.26 ha, private green terraces 0.12 ha, green escarpments 0.19 ha). The spatial structure of greenery in the complex is: grassy surfaces, low greenery in containers associated with a private space (fenced terraces) and shrubs attractively composed on the escarpments covering the walls of underground garages.

\section{Results}

A comparative analysis of selected green areas in housing estates in Bialystok allows to form the following conclusions. Housing estates designed on the basis of urban norms have the largest green areas per capita (Table 3). In addition to the very surface of green areas, spatial continuity and links with open areas are also important. An additional factor influencing the quality of these settlements is the vegetation - an appropriate ratio of high to low greenery that has a positive effect on the microclimate of intra-block spaces (Table 4). 
Table 3. Comparative analysis of greenery surface

\begin{tabular}{|ccccc|}
\hline Estate & Estate area & $\begin{array}{c}\text { Green spaces } \\
\text { area }\end{array}$ & $\begin{array}{c}\text { Population } \\
\text { Białostoczek housing estate }\end{array}$ & $\begin{array}{c}\text { Green space } \\
\text { area per } \\
\text { 1 habitant }\end{array}$ \\
\hline Nowe Miasto II housing estate & 30,0 ha ha & 22,0 ha & 10500 & $20,9 \mathrm{~m}^{2}$ \\
\hline $\begin{array}{c}\text { Apartamenty Jagiellońskie } \\
\text { residentional complex }\end{array}$ & 3,0 ha & 0,31 ha & 9400 & $6,7 \mathrm{~m}^{2}$ \\
\hline
\end{tabular}

Table 4. Comparative analysis of spatial relationships and green areas in the estates

\begin{tabular}{|lccccc|}
\hline Estate & $\begin{array}{c}\text { Interblock space } \\
\text { binding }\end{array}$ & $\begin{array}{c}\text { Rest and } \\
\text { recreation } \\
\text { areas }\end{array}$ & $\begin{array}{c}\text { Tall types } \\
\text { of flora }\end{array}$ & $\begin{array}{c}\text { Low types } \\
\text { of flora }\end{array}$ & Grassy area \\
\hline $\begin{array}{l}\text { Białostoczek housing } \\
\text { estate }\end{array}$ & +++ & ++ & ++ & ++ & +++ \\
\hline $\begin{array}{l}\text { Nowe Miasto II housing } \\
\text { estate }\end{array}$ & ++ & + & + & +++ & + \\
\hline $\begin{array}{l}\text { Apartamenty Jagiellońskie } \\
\text { residentional complex }\end{array}$ & - & - & - & + & +++ \\
\hline High degree +++ Medium degree ++ & Small degree + None- & & & + \\
\hline
\end{tabular}

The resignation from urban norms and programming of greenery only on the basis of biologically active area (including greenery on roofs and fragmented forms) led to a drastic reduction of the greenery area per capita (Table 3). It also limited common spaces to the required minimum and prevented access to compact recreation and sports areas in the place of residence. Plant cover has also changed - first of all these are grass surfaces and low greenery, which mainly has an aesthetic function (Table 4). Therefore, it becomes necessary to bring about planning changes and the separation of new green areas organized in the structure of emerging districts [Kłopotowski, 2016] as well as the development of new urban indicators conditioning the formation of a healthy housing environment giving residents the opportunity of everyday contact with nature.

\section{Literature}

[1] Dąbrowska-Milewska G. (2010), Standardy urbanistyczne dla terenów mieszkaniowych - wybrane zagadnienia, [w:] Architecturae et Artibus nr 1/2010.

[2] Dąbrowska-Milewska G., 2006 Wielorodzinna Architektura Mieszkaniowa Białegostoku. 1990-2004, Wydawnictwo Politechniki Białostockiej, Białystok.

[3] Dąbrowska-Milewska G., 2005, Rozwój osiedla Nowe Miasto II [w:] Zabudowa mieszkaniowa w ksztattowaniu przestrzeni miasta (red.) Dąbrowska-Milewska G., Wydawnictwo Politechniki Białostockiej, Białystok.

[4] Giedych R., 2015,Wskaźniki ekologiczno-przestrzenne jako standard ksztattowania zabudowy mieszkaniowej, [w:] Osiedle mieszkaniowe w strukturze przyrodniczej miasta, (red.) Szulczewska B., Wydawnictwo SGGW, Warszawa.

[5] Kobylarczyk J., 2018, Uwarunkowania środowiskowe w projektowaniu obszarów mieszkaniowych, Politechnika Krakowska, Kraków.

[6] Komar B., 2014, Wspótczesna jakość spótdzielczej przestrzeni osiedlowej w świetle zasad rozwoju zrównoważonego na wybranych przykładach, Wydawnictwo Politechniki Śląskiej, Gliwice.

[7] Kłopotowski M., 2016, Zieleń na terenie wielorodzinnych zespołów mieszkaniowych w Białymstoku, część 3 - lata 1989-2016 [w:] Tożsamość krajobrazu (red.) Kłopotowski M., Gawryluk D., Agencja Wydawnicza EkoPress, Białystok. 
[8] Lipińska A.,1977, Rola zieleni w osiedlu mieszkaniowym, PWN, Warszawa.

[9] Piątkowska K., 1976, Rekreacja w osiedlu, Zakład Wydawnictw CRS, Warszawa.

[10] Schneider-Skalska G., 2004, Kształtowanie zdrowego środowiska mieszkaniowego. Wybrane zagadnienia, Politechnika Krakowska, Kraków.

[11] Schneider-Skalska G. 2017, Zrównoważone środowisko mieszkaniowe w obszarach zurbanizowanych, [w:] Miejskie środowisko mieszkaniowe (red.) Schneider-Skalska G., Kusińska E., Politechnika Krakowska, Kraków.

[12] Skibniewska H., 1979, Tereny otwarte w miejskim środowisku mieszkaniowym, Arkady, Warszawa.

[13] Szulczewska B., Giedych R., 2011, Przestrzeń przyrodnicza i społeczna osiedli mieszkaniowych w XX i XXI wieku, Wydawnictwo SGGW, Warszawa.

[14] Zachariasz A., 2006, Zieleń jako wspótczesny czynnik miastotwórczy ze szczególnym uwzględnieniem roli parków publicznych, Politechnika Krakowska im. Tadeusza Kościuszki, Kraków.

[15] Zachariasz A., 2017, Zrównoważone środowisko mieszkaniowe w obszarach zurbanizowanych, [w:] Miejskie środowisko mieszkaniowe (red.) Schneider-Skalska G., Kusińska E., Politechnika Krakowska im. Tadeusza Kościuszki, Kraków.

\title{
Tereny zieleni osiedlowej w kształtowaniu jakości środowiska mieszkaniowego na przykładzie Białegostoku
}

\begin{abstract}
Streszczenie: Środowisko mieszkaniowe jest podstawowym obszarem funkcjonowania człowieka, które przez swoją jakość wpływa na jego stan zdrowia i samopoczucie. Jednym z głównych czynników warunkujących wysoką jakość środowiska mieszkaniowego jest odpowiedni wskaźnik terenów zieleni w przeliczeniu na 1 mieszkańca dający możliwość stworzenia przyjaznych przestrzeni wspólnych jak również charakter samej zieleni. W artykule przedstawiono analizy wybranych osiedli mieszkaniowych realizowanych w oparciu różne wytyczne i wskaźniki regulujące wielkość terenów zieleni w osiedlach. Przeprowadzone badania pozwoliły stwierdzić, iż normatywy urbanistyczne stosowane w XX w. zapewniały najlepszy wskaźnik terenów zieleni na 1 mieszkańca. Natomiast zastąpienie ich współczynnikiem powierzchni terenu biologicznie czynnego doprowadziło do minimalizacji terenów zieleni w osiedlach i konieczne staje się wypracowanie nowych wskaźników urbanistycznych w celu poprawy jakości środowiska mieszkaniowego.
\end{abstract}

Słowa klucze: tereny zieleni osiedlowej, wskaźniki urbanistyczne, normatyw urbanistyczny, środowisko mieszkaniowe, Białystok 